Journal of Management and Development Studies

Volume: 30, Issue 1, 1-13

(C) 2021 Nepal Administrative Staff College

https://doi.org/10.3126/jmds.v30i1.36345

https://www.nasc.org.np/journals/all

ISSN 2392-4896 online/ ISSN 2392-4888 print

\title{
Local development planning in Nepal: Does it actually reflect citizen participation?
}

\section{Anil Kumar Gupta}

Nepal Administrative Staff College

anil.gupta@nasc.org.np

\section{Introduction}

\begin{abstract}
Active participation and meaningful engagement of citizens in local development planning and discussion are the prime agendas of development governance in Nepal. Both state and non-state actors have placed great emphasis on citizen participation in local development planning and discussion through their plans, policies, and programmes. However, evidence shows that there is a low level of citizen participation and engagement. It is worrisome that these policies, plans, and programmes adopted by the state and non-state actors have not been able to deliver the expected results. In this regard, this paper aims to analyse citizen participation in local development planning and discussion. For this, it used the evidence generated by Nepal National Governance Survey 2017/18 and analysed the data using the logistic regression model. The results indicate that the degree of citizen participation in local development planning and discussion is relatively low. Nearly 30 percent of citizens reported that they participated in the local development planning and discussion in the past. It is remarkable to note that citizen participation varies according to their background characteristics.
\end{abstract}

Keywords: Citizen, participation, planning, development

The concern of citizen participation in local development planning can be seen globally, including in Nepal. Active and meaningful participation of citizens in development planning and discussion in Nepal is relatively recent. There are, however, some shreds of evidence in past about citizen participation in development activities. Some Kings and prime ministers were found to involve citizens in development works as labourers. Citizens, however, had no right to influence development work; they only performed their duties without saying or asking for anything. Citizen participation in development planning and governance during the authoritarian Rana regime (846-1951) was almost zero. After a long struggle, the authoritarian Rana regime was dissolved in 1951, and Nepal 
entered the modern era (Pyakuryal \& Suvedi, 2000). The whole government and administration structure was changed, but the citizens' participation was not officially legalised. Unfortunately, in 1960, King Mahendra declared a party-less Panchayat system (1960-1990), in which parties were banned, political activities were discouraged, and the rulers of "Panchayat" benefited from democracy (Devkota, 2019). In this system, the government, for the first time, officially focused on the importance of citizen participation in the process of local planning (Pandeya, 2015). In 1975, to prepare an annual district development plan for popular participation, the government issued and disseminated a guideline to all Panchayat districts, but the term popular participation was not noticeably defined (Bhusal, 2018).

The 1990 peoples' movement abolished the autocratic party-less Panchayat system and restored multiparty democracy with the promulgation of the constitution of the Kingdom of Nepal, 1990 (Government of Nepal [GoN], 1990). This constitution principally emphasised citizen's participation in local governance through decentralisation (GoN, 1990). Based on this constitution, the local self-governance act was promulgated in 1999 for the devolution of power from the central to the local level (GoN, 1999). This act provided the legislative framework for citizen participation in the making of public policies and small-scale development programmes at the local level (Bhusal, 2018). In fact, this act created legal space for inclusive and participatory local governance for citizen participation in local development planning, budgeting, project implementation, monitoring, and evaluation processes, and so on. The act stated that the planning institution was to be led by the elected leader (Bhusal, 2018), but due to the civil war (1996-2006), the local elections scheduled for 2002 were postponed and the government did not hold the elections until 2016. In the absence of elected leadership between 2002 and 2016, all the functions and activities of governance and development provided by the local self-government act were executed by centrally appointed bureaucrats (Gupta et al., 2019). During those years, the centrally appointed bureaucrats were responsible for citizen participation in local development planning. And citizens could participate in some limited ways, including in public audit, public hearing, and user groups.

The Interim Constitution of Nepal 2007 was promulgated following the Comprehensive Peace Agreement between the Government and the Communist Party of Nepal (Maoist) in November 2006. This constitution created opportunities for the maximum participation of the citizen in governance by way of self-governance (GoN, 2007). With the promulgation of the Constitution of Nepal 2015, the country transformed into the Federal Democratic Republic of Nepal. While some degree of citizen participation in local development planning was found in the past, following the promulgation of the Constitution of Nepal 2015, the government of Nepal has given more priority to citizen participation. The local government operation act 2017 , in the spirit of the constitution, stressed citizen participation, and visibly mentioned functional responsibility of the local government (GoN, 2017). This act focuses primarily on local governance, management, local development, planning, budgeting, and service delivery. The notion of citizen participation in local development planning and discussion was also reflected in the current national plan. Nepal's 15th development plan (2019/20-2023/24) has a focus on enhancing ownership in local development planning (National Planning Commission [NPC], 2019). In this backdrop, this study aimed to analyse citizen participation in local development planning in Nepal. 


\section{Citizen participation: An overview}

Notwithstanding the continued use of the word citizen participation by policymakers, development planners, scholars, and politicians, it is defined and interpreted in literature in a variety of ways. The World Bank (1996) defined participation as a process via which stakeholders sway and share power over development activities, decisions and resources that affect them. Glass (1979) described citizen participation as an opportunity for citizens to take part in government decision-making or planning processes. For Slocum et al. (1995), citizen participation is a way of communicating the interest of individuals and society about development plans, as these planning efforts affect the general public and other groups. Creighton (2005) argues that citizen participation is a process that incorporates public concerns, needs, and values into governmental and corporate decision making. As such, citizens should actively and directly be involved in decisions affecting their lives. Citizen participation bridges the gaps among the government, civil society, private sector, and general citizen; and creates a shared thought of local situation, priorities, and programmes (Yvonne, 2010). Keeping all scholars' views in mind, citizen participation can be conceptualised as a decision-making path and space where citizens are involved and engaged in the planning and development process at all levels. Citizen participation engages them in decision-making processes and promotes ownership in planning and development. It also fosters transparency, accountability, and inclusiveness in decision-making. All citizens should, therefore, have an equal opportunity to participate and get involved in planning and development.

\section{Citizen participation and development planning}

Since the 1960s, when citizen groups began to appear as notable actors in the urban scene, participatory planning has been receiving considerable attention by planners (Arnstein, 1969; Healey, 1997; Smith, 1973). Thereafter, citizen participation has become a common feature in many planning activities (Glass, 1979). Citizen participation is promoted for participatory planning, which increases the quality of the plans by making them more responsive to a diversity of interests, sinking corruption in the planning process, and creating a consensus that would make the plans workable (Chaowarat, 2010). It is often argued that citizen participation should be active and effective in all stages of planning and development. Citizens' active and effective participation confirms mutual modesty among stakeholders' needs which ultimately improve quality results. Citizen inputs help public officials to grasp public expectations better and remove unnecessary programmes, which ultimately leads to improved efficiency (Neshkova \& Guo, 2012). The success of development planning depends on the extent to which citizens are allowed to participate (Hashim, 1986; Lukic, 2011). A higher degree of citizen participation in decision-making contributes to achieving development results effectively and efficiently. There are two degrees of opportunity to influence any decision, namely before the preparation of the proposal and after the publication of the proposed plan (Marzuki, 2015). As per Marzuki, citizens submit their ideas and suggestions for planning work before the implementation of the plan, while they have another opportunity to submit their objections and amendments, if any, after the proposed plan has been published. The higher citizen participation at these two levels is both critical and significant. Effective citizen participation, according to Miskowiak (2004), is both functional for planning and meaningful to citizens. He further explains that participation is functional when it comes to better decision- 
making and solicitous community plan, and participation is meaningful when citizens have the opportunity to influence decisions and feel a sense of responsibility for the community plan.

Real development is said to begin at the local level. Local citizens know their socio-economic background and the development issues, goals, and needs much better than any outsiders. Hence, bringing government closer to the citizens is the rationale of democratic local government (Zanna, 2015). Citizen participation reflects democratic ideals, particularly at the grassroots level (Lafont, 2015; West, 2015). Shittu and Musbaudeen (2016) point out that citizens having opportunities to participate in local government have enormous advantages. It offers a sense of ownership, equity, and development sustainability (Zanna, 2015). Zanna further argues that increased participation provides direct accountability to local authorities, increasing service delivery and making better policies at the local level to address poverty. It, however, does not mean that citizen participation does not have any disadvantages. Therefore, assuming that citizen participation always leads to the desired results can be misleading (Pandeya, 2015). Irvin and Stansbury (2004) argued that participation may take a longer time, lead to higher costs, and increase the probability of improper decisions. Similarly, Marzuki (2015) argued that citizen participation is also time-consuming and sluggish decision-making because citizens need to be briefed and even first be educated to participate meaningfully in administrative processes. Pandeya and Shrestha (2016) found that participatory practices would not only mend planning efficacy but would also create free-rider, ethical hazard problems, new forms of corruption, often relying on individualistic benefits rather than equal and holistic benefits. Given the downside of citizen participation by these scholars, active and meaningful participation and engagement of citizens creates a sense of ownership that contributes to the success of the planning and development. Citizen participation and engagement is, therefore, a primary requirement that ultimately translates democracy into practices.

\section{Study methods}

The analysis of this paper is based on Nepal National Governance Survey (NNGS) 2017/18. The NNGS 2017/18 is a nationally representative survey (Nepal Administrative Staff College [NASC], 2018). This survey used a four-stage multiple cluster sampling design and selected 43 districts as a sample based on the province, urban-rural region, and ecological zone representation. This survey was conducted from December 2017 to March 2018, in which 12872 individual citizens aged 18 and over were successfully interviewed. The response rate for this survey was $99.6 \%$. The NNGS $2017 / 18$ captured information on the respondents' background and citizen participation in local development planning and discussion at some points in the past. The NNGS 2017/18 collected information about citizen participation by asking: "In the past, the government has made a lot of efforts to involve citizens in development activities. Have you ever participated in any of the planning activities or discussions in your locality?" This question had three options viz. Yes, No and Don't Know/Can't Say. In the analysis, the options such as 'Don't know/Can't Say' were omitted because they did not give a clear opinion on their participation in local development planning and discussion. Among 12,872 individual respondents, 166 reported 'Don't Know/Can't Say'. The actual sample for the analysis, therefore, became 12,706. This paper used Logistic Regression to analyse the relationship between predictor and outcome variables. Citizen participation in local development planning was used as an outcome variable and background characteristics as predictor variables. The outcome variable (citizen participation) was categorized in binary form- 
coded as a '0' for non-participation and '1' as participation in development planning and discussion. The Logistic Regression Equation Model was generated as:

$$
\ln \left\{\frac{\mathrm{P}}{1-\mathrm{P}}\right\}=k_{0}+k_{1} x_{1}+k_{2} x_{2}+\cdots k_{n} x_{n}
$$

Where,

$\mathrm{P}$ is the probability for participation in local development planning and discussion;

(1-P) is the probability of non- participation in development planning and discussion;

$k x=$ the coefficient of the predictor variables (background characteristics).

Probability of the outcome (Example: probability for participation) occurring can be expressed in the following way:

$$
\mathrm{P}=\frac{\exp \left(k_{0}+k_{1} x_{1}+\cdots+k_{n} x_{n}\right)}{1+\exp \left(k_{0}+k_{1} x_{1}+\cdots+k_{n} x_{n}\right)} \quad---(2)
$$

The slope measures the ratio of the likelihood of participation in development planning and discussion to the likelihood of non-participation in development planning and discussion in relation to each reference group. In this analysis, the odds ratio is stated because it offers a more instinctual way of interpreting effects (Mangafic \& Veselinovic, 2020). Required statistical information was generated from the SPSS version 26 , and data were tabulated and then analysed with the help of appropriate literature on citizen participation.

\section{Results}

The results present citizen participation in local development planning and discussion with the background characteristics of citizens.

Table 1: Citizen participation in local development planning and discussion by background characteristics

\begin{tabular}{llll}
\hline Background characteristics & Yes & No & Total \\
\hline Overall & 30.2 & 69.8 & 100.0 \\
Province & & & \\
Province 1 & 27.2 & 72.8 & 100.0 \\
Province 2 & 10.8 & 89.2 & 100.0 \\
Bagmati & 39.1 & 60.9 & 100.0 \\
Gandaki & 38.7 & 61.3 & 100.0 \\
Lumbini & 35.8 & 64.2 & 100.0 \\
Karnali & 30.3 & 69.7 & 100.0 \\
\hline
\end{tabular}




\begin{tabular}{|c|c|c|c|}
\hline Background characteristics & Yes & No & Total \\
\hline Sudurpashchim & 35.5 & 64.5 & 100.0 \\
\hline \multicolumn{4}{|l|}{ Ecological zone } \\
\hline Mountain & 37.8 & 62.2 & 100.0 \\
\hline Hill & 35.2 & 64.8 & 100.0 \\
\hline Tarai & 22.2 & 77.8 & 100.0 \\
\hline \multicolumn{4}{|l|}{ Urban/rural } \\
\hline Urban Municipality & 31.0 & 69.0 & 100.0 \\
\hline Rural Municipality & 29.4 & 70.6 & 100.0 \\
\hline \multicolumn{4}{|l|}{ Sex } \\
\hline Men & 40.0 & 60.0 & 100.0 \\
\hline Women & 21.2 & 78.8 & 100.0 \\
\hline \multicolumn{4}{|l|}{ Age group } \\
\hline $18-24$ & 27.9 & 72.1 & 100.0 \\
\hline $25-39$ & 32.2 & 67.8 & 100.0 \\
\hline $40-59$ & 32.2 & 67.8 & 100.0 \\
\hline 60 and above & 24.0 & 76.0 & 100.0 \\
\hline \multicolumn{4}{|l|}{ Caste/ethnic group } \\
\hline Hill Brahmin, Sanyasi & 41.7 & 58.3 & 100.0 \\
\hline Hill Chhetri, Thakuri & 36.6 & 63.4 & 100.0 \\
\hline Newar & 32.6 & 67.4 & 100.0 \\
\hline Hill Janajati & 32.6 & 67.4 & 100.0 \\
\hline Tarai Caste & 13.3 & 86.7 & 100.0 \\
\hline Tarai Janajati & 23.3 & 76.7 & 100.0 \\
\hline Dalit & 25.2 & 74.8 & 100.0 \\
\hline Muslim & 11.6 & 88.4 & 100.0 \\
\hline \multicolumn{4}{|l|}{ Education } \\
\hline No education & 16.9 & 83.1 & 100.0 \\
\hline No formal education & 33.0 & 67.0 & 100.0 \\
\hline Basic education & 37.0 & 63.0 & 100.0 \\
\hline Secondary education & 40.4 & 59.6 & 100.0 \\
\hline Higher education & 52.7 & 47.3 & 100.0 \\
\hline \multicolumn{4}{|l|}{ Occupation/usual activities } \\
\hline Agriculture & 34.9 & 65.1 & 100.0 \\
\hline
\end{tabular}




\begin{tabular}{|c|c|c|c|}
\hline Background characteristics & Yes & No & Total \\
\hline Business & 34.1 & 65.9 & 100.0 \\
\hline Service & 48.9 & 51.1 & 100.0 \\
\hline Daily wage & 26.6 & 73.4 & 100.0 \\
\hline Household chore & 17.9 & 82.1 & 100.0 \\
\hline Not working & 20.4 & 79.6 & 100.0 \\
\hline Other activity & 49.0 & 51.0 & 100.0 \\
\hline \multicolumn{4}{|l|}{ Economic status } \\
\hline Rich & 36.7 & 63.3 & 100.0 \\
\hline Medium & 34.7 & 65.3 & 100.0 \\
\hline Poor & 22.6 & 77.4 & 100.0 \\
\hline
\end{tabular}

$\chi^{2}=567.693, p<0.000, d f=6$, (province and participation); $\chi^{2}=282.579, p<0.001, d f=2,($ Ecological zone and participation); $\boldsymbol{\chi}^{2}=3.785, \mathrm{p}<0.052, \mathrm{df}=1$ (Urban/rural and participation); $\boldsymbol{\chi}^{2}=530.765$, $\mathrm{p}<0.001, \mathrm{df}=1$, (Sexand participation) $; \chi^{2}=60.222988, \mathrm{p}<0.001, \mathrm{df}=3$, (Age group and participation); $\chi^{2}=430.976137, p<0.001, \mathrm{df}=7$, (Caste/ethnicity and participation); $\boldsymbol{\chi}^{2}=709.918112, \mathrm{p}<0.001$, $\mathrm{df}=4$, (Education and participation); $\chi^{2}=633.542198, \mathrm{p}<0.001, \mathrm{df}=6$, (occupation/usual activity and participation); $\boldsymbol{\chi}^{2}=210.394844, \mathrm{p}<0.001, \mathrm{df}=2$, (Economic status and participation).

Time and again, state and non-state actors haveemphasised citizen participation in local development planning and discussion. However, evidence shows that there is low citizen participation in local development planning and discussion (NASC, 2018). Table 1 shows citizen participation in local development planning and discussion (hereafter referred to as participation) by the background of respondents. Approximately 70 percent of citizens reported that they did not participate in the past. It is remarkable to note that only $10 \%$ of citizens from province 2 participated, where nearly 40 percent of citizens from Bagmati Province and 39 percent from Gandaki Province participated. Of the three ecological zones, a higher percentage of Mountain citizens (37.8\%) participated in development planning, followed by Hill (35.2\%) and Tarai (22.2\%) citizens. In terms of sex, men $(40 \%)$ were found to participate more than women (21.2\%). Participation among those aged 60 and above was the lowest. The participation of citizens aged 25-59 years was around 5 percent higher than that of those below the age of 25, and almost 8 percent higher than those aged 60 and above. There was no significant difference in participation by the demarcation of urban/rural areas even though citizens from urban areas (31\%) were slightly higher than those from rural areas (29.4\%). Regarding caste/ethnicity, the participation of Muslims (11.6\%), Tarai Caste (13.3\%), Tarai Janajati (23.3\%), and Dalit (25.2\%) was comparatively lower than the participation of Hill Brahmin and Sanyasi $(41.7 \%)$. The level of participation increased with higher education of the citizens. Higher participation was observed for higher education citizens $(52.7 \%)$ compared to illiterate (16.9\%) and no formal education citizens (33\%). By occupation/usual activities, citizens engaged in household chore (19.9\%), daily wage (26.6\%), and not working (20.4\%) had lower participation than those engaged in service (48.9\%) and agriculture sector (34.9\%). A positive relation was observed between economic status and participation. Participation was found to increase with higher economic status. Higher participation was observed among the rich $(36.7 \%)$ and was 
lowest among the poor (22.6\%). The significance value of $\chi 2$ clearly indicates that there exists a relationship between background and citizens' participation.

Table 2: Coefficients of logistic regression for citizen participation in local development planning and discussion by background characteristics

\begin{tabular}{|c|c|}
\hline Predictor variables & Odds Ratio \\
\hline \multicolumn{2}{|l|}{ Province } \\
\hline \multicolumn{2}{|l|}{ Province 1 (Ref.) } \\
\hline Province 2 & $.480 *$ \\
\hline Bagmati & $1.440 *$ \\
\hline Gandaki & $1.604 *$ \\
\hline Lumbini & $1.743 *$ \\
\hline Karnali & .962 \\
\hline Sudurpashchim & $1.661 *$ \\
\hline \multicolumn{2}{|l|}{ Ecological zone } \\
\hline \multicolumn{2}{|l|}{ Mountain (Ref.) } \\
\hline Hill & $.713^{*}$ \\
\hline Tarai & $.551^{*}$ \\
\hline \multicolumn{2}{|l|}{ Urban/rural } \\
\hline \multicolumn{2}{|c|}{ Urban Municipality (Ref.) } \\
\hline Rural Municipality & .947 \\
\hline \multicolumn{2}{|l|}{ Sex } \\
\hline \multicolumn{2}{|l|}{ Men (Ref.) } \\
\hline Women & $.492 *$ \\
\hline \multicolumn{2}{|l|}{ Age group } \\
\hline \multicolumn{2}{|l|}{ 18-24 (Ref.) } \\
\hline $25-39$ & $1.621^{*}$ \\
\hline $40-59$ & $2.073^{*}$ \\
\hline 60 and above & $1.938^{*}$ \\
\hline \multicolumn{2}{|l|}{ Caste/ethnicity } \\
\hline \multicolumn{2}{|c|}{ Hill Brahmin, Sanyasi (Ref.) } \\
\hline Hill Chhetri, Thakuri & .967 \\
\hline Newar & .768 \\
\hline Hill Janajati & .866 \\
\hline Tarai Caste & $.637^{* *}$ \\
\hline
\end{tabular}




\begin{tabular}{ll}
\hline Predictor variables & Odds Ratio \\
\hline Tarai Janajati & .817 \\
Dalit & 1.013 \\
Muslim & .707 \\
Education & \\
No education (Ref.) & \\
No formal education & $1.881^{*}$ \\
Basic education & $2.422^{*}$ \\
Secondary education & $3.300^{*}$ \\
Higher education & $4.405^{*}$ \\
Occupation/usual activity & \\
Agriculture (Ref.) & \\
Business & $.638^{*}$ \\
Service & .833 \\
Daily wage & $.630^{*}$ \\
Household chore & $.600^{*}$ \\
Not working & $.432^{*}$ \\
Other activity & 1.412 \\
Economic status & \\
Rich (Ref.) & \\
Medium & .780 \\
Poor & $.572^{* *}$ \\
\hline$*$ p<0.001*** $* 0.005$ &
\end{tabular}

* $p<0.001 ; * * p<0.005$

Table 2 shows the Odds Ratio (OR) of citizen participation and discussion by background characteristics. Citizen participation was used as an outcome variable and background characteristics as a predictor variable. The results showed that background characteristics of the respondents played a significant role in citizen participation. A significant difference between provinces was observed. Compared to Province 1, citizens from province $2(O R=.480, p<.001)$ were less likely to participate. Conversely, citizens of Bagmati ( $O R=1.440, p<.001)$, Gandaki $(O R=1.604, p<.001)$, Lumbini $(O R=1.743, p<.001)$, and Sudurpashchim $(O R=1.661, p<.001)$ were more likely to participate. Citizen participation also varied across different ecological zones. Compared to Mountain, citizens of Hill $(O R=.713, p<.001)$ and Tarai $(O R=.551, p<.001)$ were less likely to participate. Citizens living in rural areas $(O R=.947, p>.05)$ were less likely to participate compared to urban citizens, but the difference was not statistically significant. As a result, it can be said that urban/rural is not a strong predictor. Women citizens $(O R=.492, p<.001)$ were less likely to participate compared to men. Citizens aged 18-24 were less likely to participate compared to those aged 40-59 (OR=2.073, $p<.001), 60$ and above (OR=1.938, $p<.001)$ and 25-39 (OR=1.621, 
$p<.001)$. This indicates that older citizens are more likely to participate. No significant differences in caste/ethnicity were observed. The participation was comparatively low for Tarai caste $(O R=$ $.637, p<.005)$ and Muslims (OR $=.707, p>.05)$. Citizen participation and education are positively correlated. Citizens with higher education $(O R=4.405, p<.001)$, secondary education $(O R=3.300, p$ $<.001)$, basic education $(O R=2.422, p<.001)$ and no formal education $(O R=1.881, p<.001)$ were more likely to participate than those without education. This evidence reveals that the pattern of participation increases with citizen's educational attainment. By occupation/usual activity, citizens working in agriculture sectors were slightly more likely to participate than those working on daily wages $(O R=.630, p<.001)$ and in the business sector $(O R=.833, p<.001)$. It is interesting to note that participation increases with economic status. Citizens with high economic status were more likely to participate than those with low economic status $(O R=.572, p<.005)$. Hence, it confirms that with the increase in the economic status of citizens, their participation also increases. This evidence indicates that citizen participation differs by background characteristics of citizens.

\section{Discussion}

In particular, participatory planning has been revitalised as one of the key vehicles to engage citizens in local decision-making (Bhusal, 2018). Real development begins with the active and meaningful participation of the citizens. In fact, citizen participation is at the heart of democracy, and democracy is not possible unless citizens can freely participate in the governance process (Astrom, 2019). Pimbert and Wakeford (2001) argued that democracy would become empty and meaningless without the consideration, participation, and engagement of citizens. Active and meaningful citizen participation is, therefore, a sign of democratic and participatory governance. Moroever, participation should be institutionalised. Participatory democracy can only be fully institutionalised if citizen participation is maintained positively and inclusively. Citizens deserve and are legally entitled to be participated, involved, and engaged. For this, many countries around the world, such as Nepal, have broad-based initiatives that foster citizen participation. Citizen participation has been strongly emphasised in the constitution of the Kingdom of Nepal, 1990, local self-governance act 1999, the interim constitution of Nepal 2007, the constitution of Nepal 2015, local government operation act 2017, and 15th development plan (2019/20-2023/24) (GoN, 1990, 1999, 2015, 2017; NPC, 2019). However, NNGS 2017/18 showed that only 30.2 percent of citizens participated in the local development planning and discussion in the past (NASC, 2018). This evidence reveals that local development plans and programmes are carried out without many citizens being consulted.

If development is for people, then citizen participation is a primary requirement. This is because citizen participation and engagement leads to better decision making. Citizens also have indigenous and local knowledge that contributes to better decisions in the planning and development process. The success of development planning, therefore, depends on how far the citizens are allowed to be involved and engaged (Hashim, 1986; Lukic, 2011). Indeed, citizen participation allows public officials to better understand public expectations and minimise unnecessary programmes (Neshkova \& Guo, 2012). Imposed planning and development activities cannot sustain due to a lack of ownership. It is, therefore, necessary for citizens to perceive ownership of planning and development activities, and ownership can only be confirmed if citizens take participation and get engaged. Such participation bridges the gap between citizens and the government and gives citizens the right and authority to influence local planning and development activities. 
Citizen engagement has changed the position of citizens from a development recipient to a development actor. For this, citizen capacity should be strengthened to assess and identify needs, expectations, and priorities. In this process, the roles of state and non-state actors cannot be ignored. These actors should not only be aware of the importance and value of citizen participation but should also encourage the citizens to participate and engage in the development planning process. Education and awareness programmes are much needed because Nepal has a relatively small number of literate citizens and lower literacy creates barriers. Meanwhile, participation is linked with the sharing of knowledge (Neshkova \& Guo, 2012). It develops confidence, competence, and self-awareness in citizens to influence, shape, decide, and participate in the development process (Panday \& Chowdhury, 2020). Citizens should, therefore, be educated by various means. For this purpose, awareness campaigns should be implemented effectively and efficiently with the support of media. Information should be disseminated at the community level in the local languages. If information is not readily available to citizens, citizens may face challenges for active participation and engagement. Citizens themselves, to some extent, are responsible for lower participation and engagement. Most of the citizens have not yet understood its importance and value. The citizen should, therefore, also be proactively concerned about their rights and responsibilities. They should be able to raise their voices and concerns to active participation and engagement. Their ignorance and negligence can leave a negative impact on development. They should seek to participate and engage proactively for sustainable and quality development. In the end, citizen participation and engagement must be equitable and fair, and not discriminatory, especially based on personal attributes. Inappropriate and unequal citizen participation creates a barrier for sustainable and effective planning and development.

\section{Conclusion}

Citizen participation and engagement in local development planning and discussion is the key concern among policymakers in the country. In the past, although the government of Nepal has adopted a number of policies to foster citizen participation, evidence has shown that there is low citizen participation and engagement. Now, the constitution of Nepal 2015, local government operation act 2017, and 15th development plan have strongly focused on citizen participation and engagement than ever before. The vision of 'Happy Nepali and Prosperous Nepal' cannot be fully achieved until active and meaningful participation and engagement of citizens is assured everywhere. Local-level and other institutions working in the field of development governance should ensure citizen participation and engagement at all stages of planning and development. There should be an inclusive environment for generating ownership in planning and development. The culture of citizen participation and engagement should be institutionalised. 


\section{References}

Arnstein, S. R. (1969). A ladder of citizen participation. Journal of the American Institute of Planners, 57(4), 216-224. https://doi.org/10.1080/01944366908977225

Astrom, J. (2019). Citizen participation. In The Wiley Blackwell encyclopaedia of urban and regional studies (pp. 1-4). Wiley Blackwell. https://doi.org/10.1002/9781118568446.eurs0441

Bhusal, T. (2018). Examining citizen participation in local policymaking: An analysis of Nepal's participatory planning process [Unpublished doctoral dissertation]. The University of Canberra. https://bit.ly/3gbWxJL

Chaowarat, P. (2010). Participatory planning in municipal development in Thailand [Unpublished doctoral dissertation]. The University of Berlin. https://bit.ly/2CJWaZn

Creighton, J. L. (2005). The public participation handbook: Making better decisions through citizen involvement. Jossey Bass. https://bit.ly/31dGhnl

Devkota, K. (2019). Leadership crisis in Nepali politics: Specific focus on national parties in the context of declaration of the republic. Social Inquiry: Journal of Social Science Research, 1(1), 42-51. https://doi. org/10.3126/sijssr.v1i1.26915

Glass, J. J. (1979). Citizen participation in planning: The relationship between objectives and techniques. Journal of the American Planning Association, 45(2), 180-189. https://doi.org/10.1080/01944367908976956

Government of Nepal. (1990). The constitution of the Kingdom of Nepal 1990. https://bit.ly/3iJfs0m

Government of Nepal. (1999). Local self-government act 1999. https://bit.ly/2QbFPQg

Government of Nepal. (2007). The interim constitution of Nepal 2007. https://bit.ly/3hfWy0z

Government of Nepal. (2015). The constitution of Nepal 2015. https://bit.ly/2PVISwR

Government of Nepal. (2017). Local government operation act 2017. https://bit.ly/3aJwh8|

Gupta, A. K., Poudyal, T., \& Shrestha, S. (2019). Politicians and bureaucrats' relation in local governance of Nepal. Local Government Quarterly, 5-24. https://bit.ly/34liFzi

Hashim, H. (1986). Grassroots participation in local planning process [Unpublished doctoral dissertation]. Lowa State University. https://bit.ly/31dE7Eb

Healey, P. (1997). Collaborative planning: Shaping places in fragmented societies. Macmillan International Higher Education. https://bit.ly/3ggFarp

Irvin, R. A., \& Stansbury, J. (2004). Citizen participation in decision making: Is it worth the effort? Public Administration Review, 64(1), 55-65. https://doi.org/10.1111/j.1540-6210.2004.00346.x

Lafont, C. (2015). Deliberation, participation, and democratic legitimacy: Should deliberative mini-publics shape public policy? Journal of Political Philosophy, 23(1), 40-63. https://doi.org/10.1111/jopp.12031

Lukic, I. (2011). Influence of planning and civil initiative, as a form of public intervention, on gentrification. Spatium, 25, 56-66. https://doi.org/10.2298/SPAT1125056L

Mangafic, J., \& Veselinovic, L. (2020). The determinants of corruption at the individual level: Evidence from Bosnia-Herzegovina. Economic Research-Ekonomska Istraživanja, 33(1) 1-22. https://doi.org/10.1080/1 331677X.2020.1723426

Marzuki, A. (2015). Challenges in public participation and the decision making process. Sociology \& Space, 53(1), 21-39. https://doi.org/10.5673/sip.53.1.2

Miskowiak, D. (2004). Crafting an effective plan for public participation. Center for Land Use Education. https://bit.ly/34j8Vpc

National Planning Commission. (2019). 15th development plan (2019/20-2023/24). Government of Nepal. https://bit.ly/3aqQiAA

Nepal Administrative Staff College. (2018). Nepal national governance survey 2017/18. Nepal Administrative Staff College. https://bit.ly/30zC8mS 
Neshkova, M. I., \& Guo, H. (2012). Public participation and organizational performance: Evidence from state agencies. Journal of Public Administration Research and Theory, 22(2), 267-288. https://doi-org.eres.qnl. qa/10.1093/jopart/mur038

Panday, P. K., \& Chowdhury, S. (2020). Responsiveness of local government officials: Insights and lessons from participatory planning and budgeting. Asia Pacific Journal of Public Administration,42(2), 1-20. https:// doi.org/10.1080/23276665.2020.1742753

Pandeya, G. P. (2015). Does citizen participation in local government decision-making contribute to strengthening local planning and accountability systems? An empirical assessment of stakeholders' perceptions in Nepal. International Public Management Review, 16(1), 67-98. https://bit.ly/3aHSmED

Pandeya, G. P., \& Shrestha, S. K. (2016). Does citizen participation improve local planning? An empirical analysis of stakeholders' perceptions in Nepal. Journal of South Asian Development, 11(3), 276-304. https://doi.org/10.1177\%2F0973174116667097

Pimbert, M., \& Wakeford, T. (2001). Overview: Deliberative democracy and citizen empowerment. PLA Notes, 40, 23-28. https://bit.ly/39XeSJp

Pyakuryal, K., \& Suvedi, M. (2000). Understanding Nepal's development: Context, interventions, and people's aspirations. Michigan State University. https://bit.ly/2YflbBR

Shittu, A. I., \& Musbaudeen, A. M. (2016). Public participation in local government planning and development: Evidence from Lagos State, Nigeria. Covenant University Journal of Politics and International Affairs, 2(3), 20-42. https://bit.ly/2Yi4SFO

Slocum, R., Wichhart, L., Rocheleau, D., \& Thomas-Slayter, B. (1995). Power, process, and participation: Tools for change. Intermediate Technology Development Group Publishing. https://bit.ly/327m2a5

Smith, R. W. (1973). A theoretical basis for participatory planning. Policy Sciences, 4(3), 275-295. https://bit. Iy/31clEI3

West, C. (2015). Public opinion. The Encyclopedia of Political Thought, 3038-3041. https://doi. org/10.1002/9781118474396.wbept0845

World Bank. (1996). The World Bank participation source book: Environmentally sustainable development. World Bank Publications. https://bit.ly/324IOPY

Yvonne, M. (2010). Public participation for sustainable development in local cities. In 46th ISOCARP Congress, Kenya. https://bit.ly/3aFUY5I

Zanna, A. S. (2015). Citizen participation in local governance and sustainability of programmes. Global Journal of Science Frontier Research: E Interdisciplinary, 15(3), 19-22. https://bit.ly/3kZR1xv 